\title{
Effects of smoking cessation on sexual functions and health quality of life in premenopausal women: A prospective case - controlled study
}

\author{
Hakan Celikhisar ${ }^{1}$, Gulay Dasdemir Ilkhan ${ }^{2}$, and Bora Irer ${ }^{3}$ \\ ${ }^{1}$ Affiliation not available \\ ${ }^{2}$ Okmeydani Training and Research Hospital \\ ${ }^{3}$ Izmir Metropolitan Municipality Esrefpasa Hospital
}

October 15, 2020

\begin{abstract}
Abstract Objective: To evaluate whether smoking cessation has an effect on female sexual function and quality of life. Methodology: After approval by the local ethics committee, smoking and non-smoking female participants were included in the study and all participants filled the female sexual function index (FSFI) and the short form 36 (SF-36). The same questionnaires were filled again at the 9th month control after smoking cessation. The scores of these questionnaires were compared between the groups. In addition, the FSFI and SF-36 scores of the participants in the smoking group were also compared with the scores at the 9th month after smoking cessation. Results: The rate of FSD was significantly higher in the smoking group when compared with control group $(86.0 \%$ vs $32.5 \%$; $<0,001)$. The FSFI total and sub domains score was significantly lower in the smoking group when compared control group [21.5 (min:14.4-max:28.69) and 28.9 (min:17.7-max:32.8); $\mathrm{p}<0.001$ respectively]. The rate of FSD was significantly decreased after nine months smoking cessation ( $86 \%$ to $35.1 \%$; $<<0.001)$. After smoking cessation significant improvements on FSFI total and sub-domain scores and SF-36 sub-domain scores were determined. Conclusion: In this study, it was shown that smoking negatively affected FSD and QOL when compared to healthy non-smoking women, and smoking cessation caused significant improvements in FSFI and SF-36 scores in these women after 9 months. Keywords: female sexual dysfunction, female sexual function index, smoking cessation, the Short Form 36, quality of life.
\end{abstract}

\section{Introduction}

Female sexual dysfunction (FSD) is defined as recurrent or permanent inability or difficulty in sexual desire and arousal, inability to reach orgasm, and genital pain during sexual intercourse. ${ }^{1}$ According to The National Health and Social Life Survey, the prevalence of sexual dysfunction in women is $43 \%$, while $31 \%$ in men. ${ }^{2}$ Despite its high prevalence in women, the underlying mechanisms of sexual dysfunction are less understood. There are many physiological, anatomical, psychological and social factors in the etiology of FSD, which negatively affect the quality of life (QOL). ${ }^{3}$ Diabetes mellitus, obesity, cardiovascular diseases, previous pelvic surgeries, drugs, alcohol and smoking may cause FSD by leading to impairment in vascular, hormonal and neurological balances. ${ }^{4}$

There are several hypotheses on the pathophysiological effects of smoking on sexual dysfunction. Disruption in vascular endothelium and formation of atherosclerosis due to smoking impair vascularity. In addition, the increase of free oxygen radicals in the circulation causes a decrease in nitric oxide (NO) synthesis, which is the main regulator released from endothelial cells, mediates vascular events and plays a role in smooth muscle relaxation . ${ }^{5-7}$ While all the pathophysiological mechanisms involved in smoking-induced sexual dysfunction have been studied very well in men with erectile dysfunction (ED); there are not enough studies regarding to these mechanisms in FSD. 
Smoking negatively affects the sexual functions and impairs the QOL by leading to ED in men. There are many studies in the literature showing that male sexual dysfunction and QOL improves after smoking cessation. $^{8-10}$ However, unlike men, there are few studies evaluating the effects of smoking on sexual health in women. ${ }^{11}$ And there is no study evaluated the effects of smoking cessation on both female sexual dysfunction and QOL.

In this study we aimed to present the negative effects of smoking on FSD and health related QOL and to evaluate the effects of smoking cessation on FSD and health related QOL in women.

\section{Methods:}

\section{Study Design}

The patients who admitted to smoking cessation outpatient clinics of Izmir Metropolitan Municipality Eşrefpaşa Hospital and Health University Okmeydanı Training and Research Hospital were included in study between January 2018 and March 2020, prospectively.

The study was approved by the local ethics committee with the number of 2011-KAEK-42 2018703-01 and all patients participating in the study filled the informed consent form.

\section{Patients}

Patients were divided into the two groups according the power analysis and the calculation of the sample size of the study as; 400 premenopausal women who had been smoking for at least 5 years and successfully cessated the smoking and 200 non-smoking women for a control group. Demographics and clinical characteristics of all female patients were recorded at the time of admission.

Patients who did not have sexual activity, had urological or gynecological pelvic surgery, used psychiatric drugs, resumed smoking during follow-up, and refused to complete any of the questionnaires were excluded from the study.

Study protocol

Three-part questionnaires were applied to the patients; the first part of questionnaire was consisted of demographics and clinical characteristics of patients including age, height, weight, systemic diseases, previous surgeries, smoking, medications and alcohol use.

The second part of the questionnaire was consisted of Female Sexual Function Index (FSFI) questionnaire to evaluate the sexual functions of the female patients. FSFI includes 19 items scored between the ranges 2-36. The FSFI contains 6 fields including; desire, arousal, lubrication, orgasm, satisfaction, and pain. In each field the score is evaluated and multiplied by the factor of the field (0.3-0.6) to attain the score. The total FSFI score of 26.55 or less was defined as the FSD. ${ }^{12}$

The third part of the questionnaire was consisted of Short-Form 36 Health Survey (SF-36) questionnaire which has 8 sub-domains like; role limitation due to physical problems, role restriction due to emotional problems, social and physical functioning, mental and general health, vitality and pain. ${ }^{13}$ Scores belonging to each sub-domain were calculated separately for the patients and zero score indicates the lowest life quality and 100 indicates the highest life quality.

All of the patients and the participants of control group filled these questionnaires at the admission of smoking cessation outpatient clinics and the $9^{\text {th }}$ month controls. Demographics, clinical characteristics and the results of the questionnaires were compared between the two groups.

Statistical analysis

The data were analyzed using Statistical Package for the Social Sciences (SPSS, Inc., Chicago IL), version 22 , software for Windows. Whether the variables were normally distributed was determined by KolmogorovSmirnov and Shapiro-Wilk normality tests. Student t test and Mann-Whitney U test were used for comparison of continuous variables between groups, and Chi-square test was used for comparison of categorical 
variables. Pearson correlation test was used to evaluate the relationships between parameters. Wilcoxon test was used to compare FSFI and SF-36 questionnaire scores before and after smoking cessation. The results were presented as median (min-max), mean \pm standard deviation (sd), percentage (\%) and number (n). P value less than 0.05 was considered statistically significant.

\section{Results :}

A total of 556 premenopausal female patients (395 smoking and 191 control) were included in this study. The mean age of the patients was $33.6 \pm 8.5$ years. The comparison of the groups according to the demographics and the clinical characteristics was given in Table 1. The total FSFI score was significantly lower in the smoking group [21.5 (min:14.4-max:28.69) and 28.9 (min:17.7-max:32.8); $\mathrm{p}<0.001$ respectively]. The rate of FSD was significantly higher in the smoking group when compared with control group $(86.0 \%$ vs $32.5 \%$; $\mathrm{p}<0,001)$. Also all of the sub-domain scores of the FSFI questionnaire and the SF-36 questionnaires were found to be statistically lower in the smoking group (Table 1). A significant negative correlation between the duration of smoking and FSFI total scores was found in smoking group $(\mathrm{r}=-0.633, \mathrm{p}<0.001)$. A statistically significant strong negative correlation was found between the duration of smoking and sexual satisfaction $(\mathrm{r}=-0.640, \mathrm{p}<0.001)$. However, there was a statistically significant but weak correlation between other FSFI sub-domain scores and duration of smoking (Table 2). Also a week correlation was detected between the duration of smoking and the SF-36 sub-domain scores; and between the FSFI total score and SF-36 subdomain scores (Table 2).

The rate of FSD was significantly decreased after nine months smoking cessation ( $86 \%$ to $35.1 \%$; $<<0.001$ ). There were statistically significant improvements after cessation smoking in total FSFI score and FSFI subdomain scores including desire, arousal, lubrication, orgasm, sexual satisfaction and pain (Table 3). Smoking cessation also caused statistically significant improvements in SF-36 sub-domain scores, especially in physical role and emotional role sub-domains (Table 3).

\section{Discussion:}

While there are many studies in the literature showing the positive effects of smoking cessation on ED in men, ${ }^{10}$ there are very few studies showing the relationship between FSD and smoking, ${ }^{11}$ and moreover, there are no studies investigating the effect of smoking cessation on FSD.

Sexual activity is process including desire, desire, arousal, lubrication, orgasm and satisfaction follows each other in women. Many psycho-physiological mechanisms such as hormonal, vascular and neural play a role in this process. ${ }^{14}$ Risk factors that lead to decreased blood flow of female external genital organs cause impairment in the arousal and lubrication phases. Disruption in these stages can cause dyspareunia, preventing sexual intercourse from reaching orgasm and satisfaction, and may lead to FSD. There are studies in the literature showing that clitoral vascularization and clitoral tissue perfusion are associated with FSD in healthy women. ${ }^{15,16}$ It has been revealed that smoking, which is one of the main risk factors of cardiovascular and cerebrovascular diseases, decreases genital vascularization. ${ }^{15-17}$ Also, the anti-estrogenic effect of smoking causes a decrease in estrogen levels, which leads to a decrease in blood flow of the genital organs. ${ }^{15-17}$ The reduction in genital vascularization (especially the impairment of the clitoral tissue perfusion), negatively affects the arousal and lubrication phases, which are very important for orgasm and satisfaction. ${ }^{18}$ Coppalo et al. demonstrated that clitoral tissue perfusion was worse in women with FSD according to FSFI total scores. ${ }^{16}$ However, no difference was found between the groups in terms of smoking. ${ }^{16}$ Choi et al. showed that women who had a smoking history, had lower FSFI total score and sub-domain scores than women who did not smoke. ${ }^{11}$ Similarly, in our study, we demonstrated that there was a significant decrease in the total scores of the FSFI questionnaire and especially in the arousal and lubrication domain scores in smoking patients.

In this study, it was shown that there is an inverse relationship between smoking duration and total FSF scores and sub domain scores. Choi et al. demonstrated that there was a dose-response relationship between smoking and FSD. ${ }^{11}$ They found that higher cumulative smoking (package years) was related to lower total FSFI score. ${ }^{11}$ The findings of this study and our study may be important in terms of showing that the effects of smoking on female sexual functions are time and dose dependent. 
There are studies in the literature that show that the deterioration in women's sexual health for various reasons, affects the QOL of women. It has been demonstrated in studies conducted in women with depression, menopause, and salpingo-oophorectomy to reduce the risk of breast cancer that FSD has a negative impact on QOL. ${ }^{19-21}$ Goldenberg et al showed that there was a negative relationship between smoking and QOL and that this relationship was directly proportional to the number of cigarettes smoked. ${ }^{22}$ In this study, we demonstrated that smoking causes FSD and negatively affects the QOL in all sub-domains. We also showed that there was a relationship between severity of FSD and QOL sub-domain scores. It can be deduced from the findings of our study that, smoking both negatively affects the QOL by causing FSD and that smoking has a direct negative effect on QOL. In addition, it can be deduced that smoking cessation may lead to improvement in FSD, thus both the improvement in FSD and the elimination of the negative effect caused by smoking can increase the QOL.

Although there are studies evaluating the effect of smoking cessation on QOL in the literature, there are no studies investigating the effect of smoking cessation on FSD. ${ }^{23,24}$ In this study, unlike the literature, changes in FSD and QOL in female smoking patients after smoking cessation were evaluated together. Our results showed that smoking cessation significantly improved both FSFI total and sub-domain scores and SF-36 sub-domain scores especially physical and emotional role subdomain scores. The reasons for the improvement in FSD after smoking cessation may be the increase in blood flow in the genital area, especially in the vagina and clitoral tissue; the decrease in oxidative stress, and the disappearance of the anti-estrogenic effects of smoking. As a result of these pathophysiological improvements, the increase in blood supply in the vagina and clitoral tissue can lead to an improvement in arousal and lubrication and resulting ease of reaching orgasm and satisfaction. Also, improvement in lubrication may prevent pain during sexual intercourse. These improvements mentioned above may also explain the improvement in FSD and thus the improvement in QOL, as shown in the results of our study.

In this study, the positive effects of smoking cessation were mostly observed in the arousal, lubrication and orgasm sub-domains of the FSFI questionnaire and in the sub domains of the SF-36 questionnaire where the physical and emotional role problems were evaluated. According to these results, it can be concluded that FSD, which is in the arousal, lubrication and orgasm stages, causes physical and emotional problems in women and impairs the QOL.

\section{Limitation:}

Our study has some limitations. The main limitation of this study was its dependence on only the results of questionnaires. Another limitation may be that the status of the partners involved in the sexual activities of the women participating in the study was not questioned. However, the strength of this study is; it is the first study in the literature evaluating the effects of smoking cessation on FSD and QOL.

\section{Conclusions:}

In conclusion, according to the results of our study, it was revealed that smoking negatively affected FSD and QOL when compared to healthy non-smoking women, and smoking cessation caused significant improvements in FSFI and SF-36 scores in these women after 9 months.

Conflict of interest: none declared

Acknowledgements: none declared

\section{References:}

1. Basson R, Berman J, Burnett A, Derogatis L, Ferguson D, Fourcroy J, et al. Report of the international consensus development conference on female sexual dysfunction: definitions and classifications. $J$ Urol 2000;163:888-93. https://doi.org/10.1016/S0022-5347(05)67828-7

2. Laumann EO, Paik A, Rosen RC. Sexual dysfunction in the United States: prevalence and predictors. JAMA . 1999;281(6):537-44. https://doi: 10.1001/jama.281.6.537 
3. Nappi R, Salonia A, Traish AM, van Lunsen RH, Vardi Y, Kodiglu A, et al. Clinical biologic pathophysiologies of women's sexual dysfunction.J Sex Med 2005;2:4-25 https://doi: 10.1111/j.17436109.2005.20102.x.

4. Polland AR, Davis M, Zeymo A, Iglesia CB. Association between comorbidities and female sexual dysfunction: findings from the third National Survey of Sexual Attitudes and Lifestyles (Natsal-3).Int Urogynecol J . 2019 Mar;30(3):377-383. https://doi: 10.1007/s00192-018-3739-7

5. Burnett AL, Lowenstein CJ, Bredt DS, Chang TS, Snyder SH. Nitric oxide: a physiologic mediator of penile erection. Science . 1992;257:401-3. https://doi: 10.1126/science.1378650.

6. Kim N, Azadzoi KM, Goldstein I, Saenz de Tejada I. A nitric oxide-like factor mediates nonadrenergicnoncholinergic neurogenic relaxation of penile corpus cavernosum smooth muscle. J Clin Invest . 1991;88:112-8. https://doi: 10.1172/JCI115266.

7. Chalon S, Moreno H Jr, Benowitz NL, Hoffman BB, Blaschke TF. Nicotine impairs endotheliumdependent dilatation in human veins in vivo.Clin Pharmacol Ther . 2000;67:391-7. https://doi: $10.1067 /$ mcp.2000.105153.

8. Tengs TO, Osgood ND. The link between smoking and impotence: two decades of evidence. Prev Med . 2001; 32:447-52. https://doi: 10.1006/pmed.2001.0830.

9. Cao S, Gan Y, Dong X, Liu J, Lu Z. Association of quantity and duration of smoking with erectile dysfunction: a dose-response meta-analysis. J Sex Med . 2014; 11(10):2376-84. https://doi: $10.1111 /$ jsm. 12641

10. Sahin MO, Sen V, Gunduz G, Ucer O. Effect of smoking cessation on sexual functions in men aged 30 to 60 years. Int Braz J Urol . 2020 Jul-Aug; 46(4): 642-648. https://doi: 10.1590/S16775538.IBJU.2019.0541

11. Choi J, Shin DW, Lee S, Jeon MJ, Kim SM, Cho B, et al.. Dose-response relationship between cigarette smoking and female sexual dysfunction. Obstet Gynecol Sci . 2015 Jul; 58(4): 302-308. https://doi: 10.5468/ogs.2015.58.4.302

12. Wiegel M, Meston C, Rosen R. The female sexual function index (FSFI): cross-validation and development of clinical cutoff scores. J Sex Marital Ther . 2005;31(1):1-20 https://doi: $10.1080 / 00926230590475206$

13. Jenkinson C, Coulter A, Wright L. Short form 36 (SF-36) health survey questionnaire: normative data for adults of working age. BMJ . 1993;29:1437-40 https://doi: 10.1136/bmj.307.6901.449.

14. Maseroli E, Scavello I, Vignozzi L. Cardiometabolic risk andfemale sexuality-Part I. Factors and potential pathophysiologicalunderpinnings for female vasculogenic sexual dysfunction syndromes. Sex Med Rev . 2018;6:508-24. https://doi: 10.1016/j.sxmr.2018.02.009

15. Battaglia C, Battaglia B, Mancini F, Persico N, Nappi RE, Paradisi R, et al. Cigarette smoking decreases the genital vascularizationin young healthy, eumenorrheic women. J Sex Med . 2011;8:171725. https://doi: 10.1111/j.1743-6109.2011.02257.x

16. Coppola A, Gallotti P, Choussos D, Pujia A, Montalcini T, Gazzaruso C. Association between clitoral tissue perfusion and female sexual dysfunction in healthy women of reproductive age: a pilot study.Int J Impot Res . 2020 Mar;32(2):221-225. https://doi: 10.1038/s41443-019-0155-6.

17. Tziomalos K, Charsoulis F. Endocrine effects of tobacco smoking. Clin Endocrinol 2004;61:664-74. https://doi: 10.1111/j.1365-2265.2004.02161.x

18. Caruso S, Rugolo S, Mirabella D, Intelisano G, Di Mari L, Cianci A. Changes in clitoral blood flow in premenopausal women affected by type 1 diabetes after single 100-mg administration of sildenafil.Urology . 2006;68:161-5. https://doi: 10.1016/j.urology.2006.01.059

19. Tutoglu A, Boyaci A, Koca I, Celen E, Kormaz N. Quality of life, depression, and sexual dysfunction in spouses of female patients with fibromyalgia. Rheumatol Int . 2014;34(8):1079-84. https://doi: $10.1007 / \mathrm{s} 00296-014-2944-\mathrm{z}$.

20. Nappi RE, Lachowsky M. Menopause and sexuality: prevalence of symptoms and impact on quality of life. Maturitas . 2009 Jun 20;63(2):138-41. https://doi: 10.1016/j.maturitas.2009.03.021

21. Tucker PE, Saunders C, Bulsara MK, Tan JJ, Salfinger SG, Green H, et al. Sexuality and quality of life in women with a prior diagnosis of breast cancer after risk-reducing salpingo-oophorectomy.Breast 
. 2016 Dec;30:26-31. https://doi: 10.1016/j.breast.2016.08.005

22. Goldenberg M, Danovitch I, IsHak WW. Quality of life and smoking. Am J Addict . 2014;23(6):540-62. https:// doi: 10.1111/j.1521-0391.2014.12148.x

23. Bloom EL, Minami H, Brown RA, Strong DR, Riebe D, Abrantes AM. Quality of life after quitting smoking and initiating aerobic exercise. Psychol Health Med . 2017;22(9):1127-35. https://doi: 10.1080/13548506.2017.1282159.

24. Chen PC, Kuo RN, Lai CK, Tsai ST, Lee YC. The relationship between smoking status and healthrelated quality of life among smokers who participated in a 1-year smoking cessation programme in Taiwan: a cohort study using the EQ-5D. BMJ Open . 2015;5: e007249. https://doi: 10.1136/bmjopen2014-007249

25. Lin JH, Ho DR, Shi CS, Chen CS, Li JM, Huang YC. The influence of smoking exposure and cessation on penile hemodynamics and corporal tissue in a rat model. Transl Androl Urol . 2020; 9(2): 637-645. https://doi: 10.21037/tau.2019.12.45

Table 1: Comparison of demographics and clinical characteristics, FSFI and SF-36 domain scores between the smoking and control groups

\begin{tabular}{|c|c|c|c|}
\hline & Control group $N=191$ & $\begin{array}{l}\text { Smoking group } \\
\mathrm{N}=365\end{array}$ & $P$ value \\
\hline Demographic data & Demographic data & Demographic data & Demographic data \\
\hline Age (year) mean \pm SD & $33.0 \pm 8.0$ & $34.0 \pm 8.7$ & 0.153 \\
\hline $\begin{array}{l}\mathrm{BMI}\left(\mathrm{kg} / \mathrm{m}^{2}\right) \\
\text { mean } \pm \mathrm{SD}\end{array}$ & $26.4 \pm 4.3$ & $27.5 \pm 4.6$ & 0.008 \\
\hline $\begin{array}{l}\text { Smoking duration } \\
\text { (package year) } \\
\text { mean } \pm \text { SD }\end{array}$ & - & $14.3 \pm 13.1$ & - \\
\hline $\begin{array}{l}\text { Comorbidity n(\%) Yes } \\
\text { No }\end{array}$ & $44(23.0 \%) 147 / 77.0 \%)$ & $99(27.1 \%) 266(72.9 \%)$ & 0.295 \\
\hline Hypertension n(\%) & $36(18.8 \%)$ & $88(24.1 \%)$ & 0.157 \\
\hline Diabetes mellitus $\mathrm{n}(\%)$ & $19(9.9 \%)$ & $28(7.7 \%)$ & 0.360 \\
\hline $\begin{array}{l}\text { Coronary artery } \\
\text { disease } \mathrm{n}(\%)\end{array}$ & $20(10.5 \%)$ & $52(14.2 \%)$ & 0.208 \\
\hline $\begin{array}{l}\text { Alcoholn }(\%) \text { Yes } \\
\text { No }\end{array}$ & $17(8.9 \%) 174(91.1 \%)$ & $29(7.9 \%) 336(92.1 \%)$ & 0.698 \\
\hline $\begin{array}{l}\text { Use psychotropic } \\
\text { medicationn }(\%) \text { Yes } \\
\text { No }\end{array}$ & $23(12.0 \%) 168(88.0 \%)$ & $48(13.2 \%) 317(86.8 \%)$ & 0.710 \\
\hline $\begin{array}{l}\text { Marital status n(\%) } \\
\text { Married Divorced }\end{array}$ & $188(98.4 \%) 3(1.6 \%)$ & $362(99.2 \%) 3(0.8 \%)$ & 0.418 \\
\hline Education level n (\%) & $38(19.9 \%) 75(39.3 \%) 78$ & $93(25.5 \%) 149(40.8 \%)$ & 0.174 \\
\hline $\begin{array}{l}\text { Primary and secondary } \\
\text { school } \\
\text { High school } \\
\text { Collage and higher } \\
\text { education }\end{array}$ & $(40.8 \%)$ & $123(33.7 \%)$ & \\
\hline FSFI domain score & FSFI domain score & FSFI domain score & FSFI domain score \\
\hline $\begin{array}{l}\text { Desire median } \\
(\min -\max )\end{array}$ & $4.2(2.4-4.8)$ & $3.0(1.2-4.2)$ & $<0.001$ \\
\hline $\begin{array}{l}\text { Arousal median } \\
(\min -\max )\end{array}$ & $4.2(2.7-6.0)$ & $2.7(1.8-4.8)$ & $<0.001$ \\
\hline $\begin{array}{l}\text { Lubricationmedian } \\
(\min -\max )\end{array}$ & $5.4(2.7-6.0)$ & $3.9(2.1-6.0)$ & $<0.001$ \\
\hline
\end{tabular}




\begin{tabular}{|c|c|c|c|}
\hline & Control group $N=191$ & $\begin{array}{l}\text { Smoking group } \\
\mathrm{N}=365\end{array}$ & $\mathbf{P}$ value \\
\hline $\begin{array}{l}\text { Orgasm median } \\
(\text { min-max })\end{array}$ & $5.2(2.4-6.0)$ & $3.6(2.4-5.2)$ & $<0.001$ \\
\hline $\begin{array}{l}\text { Sexual Satisfaction } \\
\text { median (min-max) }\end{array}$ & $4.8(2.4-6.0)$ & $4.0(2.4-5.2)$ & $<0.001$ \\
\hline $\begin{array}{l}\text { Pain median } \\
\text { (min-max })\end{array}$ & $4.0(3.2-5.2)$ & $3.6(2.4-5.6)$ & $<0.001$ \\
\hline $\begin{array}{l}\text { Total FSFI score } \\
\text { median (min-max) }\end{array}$ & $28.9(17.7-32.8)$ & $21.5(14.4-28.6)$ & $<0.001$ \\
\hline $\begin{array}{l}\text { FSD n }(\%) \text { Yes } \\
\text { No }\end{array}$ & $62(32.5 \%) 129(67.5 \%)$ & $314(\% 86.0) 51(\% 14.0)$ & $<0.001$ \\
\hline SF-36 domain score & SF-36 domain score & SF-36 domain score & SF-36 domain score \\
\hline $\begin{array}{l}\text { Bodily pain median } \\
\text { (min-max) }\end{array}$ & $100.0(67.5-100.0)$ & $67.5(22.5-100.0)$ & $<0.001$ \\
\hline $\begin{array}{l}\text { Social functioning } \\
\text { median (min-max) }\end{array}$ & $87.5(50.0-100.0)$ & $50.0(12.5-100.0)$ & $<0.001$ \\
\hline $\begin{array}{l}\text { Physical function } \\
\text { median (min-max) }\end{array}$ & $100.0(60.0-100.0)$ & $70.0(0.0-100.0)$ & $<0.001$ \\
\hline $\begin{array}{l}\text { Role physical median } \\
\text { (min-max) }\end{array}$ & $100.0(25.0-100.0)$ & $25.0(0.0-100.0)$ & $<0.001$ \\
\hline $\begin{array}{l}\text { Role emotional median } \\
(\min -\max )\end{array}$ & $100.0(0.0-100.0)$ & $33.3(0.0-100.0)$ & $<0.001$ \\
\hline $\begin{array}{l}\text { Vitality median } \\
(\text { min-max })\end{array}$ & $60.0(30.0-100.0)$ & $35.0(0.0-80.0)$ & $<0.001$ \\
\hline $\begin{array}{l}\text { Mental health median } \\
(\min -\max )\end{array}$ & $76.0(48.0-88.0)$ & $56.0(12.0-84.0)$ & $<0.001$ \\
\hline $\begin{array}{l}\text { General health median } \\
\text { (min-max) }\end{array}$ & $60.0(35.0-90.0)$ & $35.0(0.0-90.0)$ & $<0.001$ \\
\hline
\end{tabular}

BMI, Body Mass Index; FSFI, Female Sexual Function Index; FSD, Female Sexual Dysfunction; SF-36, Short form-36; Student T test and Mann-Whitney U Test for continuous variable and Chi-square test for categorical variable.

Table 2: Evaluation of correlation between FSFI scores, SF-36 scores and duration of smoking

\begin{tabular}{|c|c|c|c|c|c|c|c|c|}
\hline $\begin{array}{l}\text { FSFI } \\
\text { sub- } \\
\text { domain }\end{array}$ & Desire & Arousal & Lubrication & Orgasm & $\begin{array}{l}\text { Sexual } \\
\text { Satis- } \\
\text { faction }\end{array}$ & Pain & $\begin{array}{l}\text { Total } \\
\text { FSI }\end{array}$ & \\
\hline $\begin{array}{l}\text { Smoking } \\
\text { duration } \\
\text { (package } \\
\text { year) }\end{array}$ & $\begin{array}{l}\mathrm{r}=-0.491 \\
\mathrm{p}<0.001\end{array}$ & $\begin{array}{l}\mathrm{r}=-0.396 \\
\mathrm{p}<0.001\end{array}$ & $\begin{array}{l}\mathrm{r}=-0.576 \\
\mathrm{p}<0.001\end{array}$ & $\begin{array}{l}\mathrm{r}=-0.463 \\
\mathrm{p}<0.001\end{array}$ & $\begin{array}{l}\mathrm{r}=-0.640 \\
\mathrm{p}<0.001\end{array}$ & $\begin{array}{l}\mathrm{r}=-0.365 \\
\mathrm{p}<0.001\end{array}$ & $\begin{array}{l}\mathrm{r}=-0.633 \\
\mathrm{p}<0.001\end{array}$ & \\
\hline $\begin{array}{l}\text { SF-36 } \\
\text { sub- } \\
\text { domain }\end{array}$ & $\begin{array}{l}\text { Bodily } \\
\text { pain }\end{array}$ & $\begin{array}{l}\text { Social } \\
\text { func- } \\
\text { tioning }\end{array}$ & $\begin{array}{l}\text { Physical } \\
\text { func- } \\
\text { tion }\end{array}$ & $\begin{array}{l}\text { Role } \\
\text { physi- } \\
\text { cal }\end{array}$ & $\begin{array}{l}\text { Role } \\
\text { emo- } \\
\text { tional }\end{array}$ & Vitality & $\begin{array}{l}\text { Mental } \\
\text { health }\end{array}$ & $\begin{array}{l}\text { Gener } \\
\text { health }\end{array}$ \\
\hline Smoking & $\mathrm{r}=-0.225$ & $\mathrm{r}=-0.261$ & $\mathrm{r}=-0.136$ & $\mathrm{r}=-0.200$ & $\mathrm{r}=-0.201$ & $\mathrm{r}=-0.302$ & $\mathrm{r}=-0.358$ & $\mathrm{r}=-0.33$ \\
\hline $\begin{array}{l}\text { duration } \\
\text { (package } \\
\text { year) }\end{array}$ & $\mathrm{p}<0.001$ & $\mathrm{p}<0.001$ & $\mathrm{P}=0.009$ & $\mathrm{p}<0.001$ & $\mathrm{p}<0.001$ & $\mathrm{p}<0.001$ & $\mathrm{p}<0.001$ & $\mathrm{p}<0.00$ \\
\hline
\end{tabular}




\begin{tabular}{lllllllll}
\hline $\begin{array}{l}\text { FSFI } \\
\text { sub- } \\
\text { domain }\end{array}$ & Desire & Arousal & Lubrication & Orgasm & $\begin{array}{l}\text { Sexual } \\
\text { Satis- } \\
\text { faction }\end{array}$ & Pain & $\begin{array}{l}\text { Total } \\
\text { FSI }\end{array}$ \\
\hline $\begin{array}{l}\text { Total FSFI } \\
\text { score }\end{array}$ & $\mathrm{r}=0.280$ & $\mathrm{r}=0.312$ & $\mathrm{r}=0.249$ & $\mathrm{r}=0.267$ & $\mathrm{r}=0.232$ & $\mathrm{r}=0.330$ & $\mathrm{r}=0.364$ & $\mathrm{r}=0.417$ \\
\hline
\end{tabular}

FSFI, Female Sexual Function Index; Pearson Correlation was used.

Table 3: The effects of smoking cessation on FSI and SF-36 domain scores

\begin{tabular}{|c|c|c|c|}
\hline & During smoking & After cessation & Pvalue \\
\hline \multicolumn{4}{|l|}{ FSI domain score } \\
\hline $\begin{array}{l}\text { Desire median } \\
\text { (min-max) }\end{array}$ & $3.0(1.2-4.2)$ & $4.2(2.4-4.8)$ & $<0.001$ \\
\hline $\begin{array}{l}\text { Arousal median } \\
(\text { min-max })\end{array}$ & $2.7(1.8-4.8)$ & $4.2(2.7-5.4)$ & $<0.001$ \\
\hline $\begin{array}{l}\text { Lubricationmedian } \\
\text { (min-max) }\end{array}$ & $3.9(2.1-6.0)$ & $5.4(2.7-6.0)$ & $<0.001$ \\
\hline $\begin{array}{l}\text { Orgasm median } \\
(\text { min-max })\end{array}$ & $3.6(2.4-5.2)$ & $5.2(3.2-6.0)$ & $<0.001$ \\
\hline $\begin{array}{l}\text { Sexual Satisfaction } \\
\text { median (min-max) }\end{array}$ & $4.0(2.4-5.2)$ & $4.8(2.4-6.0)$ & $<0.001$ \\
\hline $\begin{array}{l}\text { Pain median } \\
(\min -\max )\end{array}$ & $3.6(2.4-5.6)$ & $4.0(3.2-5.2)$ & $<0.001$ \\
\hline $\begin{array}{l}\text { Total FSI score median } \\
\text { (min-max })\end{array}$ & $21.5(14.4-28.6)$ & $28.7(17.7-32.6)$ & $<0.001$ \\
\hline $\begin{array}{l}\text { FSD n }(\%) \text { Yes } \\
\text { No }\end{array}$ & $314(86.0 \%) 51(14.0 \%)$ & $128(35.1 \%) 237(64.9 \%)$ & $<0.001$ \\
\hline \multicolumn{4}{|l|}{ SF-36 domain score } \\
\hline $\begin{array}{l}\text { Bodily painmedian } \\
\text { (min-max) }\end{array}$ & $67.5(22.5-100.0)$ & $100.0(67.5-100)$ & $<0.001$ \\
\hline $\begin{array}{l}\text { Social } \\
\text { functioningmedian } \\
\text { (min-max) }\end{array}$ & $50.0(12.5-100.0)$ & $87.5(50.0-100.0)$ & $<0.001$ \\
\hline $\begin{array}{l}\text { Physical } \\
\text { functionmedian } \\
\text { (min-max) }\end{array}$ & $70.0(0.0-100.0)$ & $100.0(60.0-100.0)$ & $<0.001$ \\
\hline $\begin{array}{l}\text { Role physical median } \\
\text { (min-max) }\end{array}$ & $25.0(0.0-100.0)$ & $100.0(25.0-100)$ & $<0.001$ \\
\hline $\begin{array}{l}\text { Role emotionalmedian } \\
\text { (min-max) }\end{array}$ & $33.3(0.0-100.0)$ & $100.0(0.0-100.0)$ & $<0.001$ \\
\hline $\begin{array}{l}\text { Vitalitymedian } \\
\text { (min-max) }\end{array}$ & $35.0(0.0-80.0)$ & $60.0(30.0-100.0)$ & $<0.001$ \\
\hline $\begin{array}{l}\text { Mental healthmedian } \\
\text { (min-max) }\end{array}$ & $56.0(12.0-84.0)$ & $72.0(48.0-88.0)$ & $<0.001$ \\
\hline $\begin{array}{l}\text { General healthmedian } \\
\text { (min-max) }\end{array}$ & $35.0(0.0-90.0)$ & $60.0(35.0-90.0)$ & $<0.001$ \\
\hline
\end{tabular}

FSFI, Female Sexual Function Index; FSD, Female Sexual Dysfunction; SF-36, Short form-36; Wilcoxon test 
was used comparison of variables before and after smoking cessation.

\section{Hosted file}

Table 1.pdf available at https://authorea.com/users/367440/articles/486868-effects-ofsmoking-cessation-on-sexual-functions-and-health-quality-of-life-in-premenopausal-womena-prospective-case-controlled-study

\section{Hosted file}

Table 2.pdf available at https://authorea.com/users/367440/articles/486868-effects-ofsmoking-cessation-on-sexual-functions-and-health-quality-of-life-in-premenopausal-womena-prospective-case-controlled-study

\section{Hosted file}

Table 3.pdf available at https://authorea.com/users/367440/articles/486868-effects-ofsmoking-cessation-on-sexual-functions-and-health-quality-of-life-in-premenopausal-womena-prospective-case-controlled-study 